\title{
A Practical Model of the Natural Attenuation of Oil on Shorelines for Decision Support
}

\author{
E. Owens ${ }^{1}$ *, E. Taylor ${ }^{2}$, G. Sergy ${ }^{3}$, K. Lee ${ }^{4}$, C. J. An ${ }^{5}$, and Z. Chen ${ }^{5}$ \\ ${ }^{1}$ Owens Coastal Consultants Ltd., 755 Winslow Way East \# 205, Bainbridge Island, WA 98110, USA \\ ${ }^{2}$ Polaris Applied Sciences, Inc., Bainbridge Island, WA 98110, USA \\ ${ }^{3} S 3$ Environmental, Edmonton, $A B$ T6J 7G3, Canada \\ ${ }^{4}$ Fisheries and Oceans Canada, Ottawa, ON K1A OE6, Canada \\ ${ }^{5}$ Department of Building, Civil and Environmental Engineering, Concordia University, Montreal H3G 1M8, Canada
}

Received 07 December 2020; revised 04 January 2021; accepted 09 February 2021; published online 04 April 2021

\begin{abstract}
Oil stranded on shorelines naturally weathers and attenuates at rates that are a function of the character of the oil on the shoreline (type and volume), the character of the shoreline materials, and the environmental setting (physical and biological). Some light crude oils and refined products have a very short half-life and may persist for only hours or days. However, if stranded oil is not exposed to light, oxygen or physical shore-zone processes, such as in asphalt pavements or if buried by marine or river sediments, it may take long time periods to fully degrade, or in a few extreme cases may not degrade at all. This review assesses the current state-of-knowledge of the natural weathering and attenuation of oil on shorelines as this relates to decisions regarding a shoreline treatment program. This knowledge is critical for the creation of simulation models for natural attenuation. The Shoreline Response Program-Decision Support Tool, currently under development, considers the various translocation (transport) pathways of oil on shorelines into the atmosphere or the marine environment and the attenuation processes that lead to the final transformation of stranded petroleum hydrocarbons into nonhydrocarbon materials. This ultimate transformation to a non-hydrocarbon is only achieved during chemical attenuation processes associated with biodegradation or photodegradation acting on exposed oil surfaces. Understanding the processes that act on the stranded oil and the rates by which oil is transformed into non-hydrocarbon materials is crucial in the decision process on whether to let Nature take its course or to intervene to remove the oil and/or accelerate the weathering and attenuation processes. This review evaluates the current state-of-understanding regarding the initial behavior and ultimate fate of oil on shorelines, identifies knowledge gaps regarding the behavior and ultimate fate of oil on shorelines, and recommends topics for further investigation and future research.
\end{abstract}

Keywords: Shoreline oil, oil transformation, oil translocation, oil weathering, oil attenuation, oil spill modeling.

\section{Introduction}

Oil stranded on shorelines changes in response to a set of biological, chemical and physical processes, variously termed attenuation, degradation, transformation or weathering, that alter the properties and character of the oil through time. These processes may involve the movement, or translocation, by one or more pathways from one location or environment (land, sea or air) to another. Understanding these processes and pathways is critical for two reasons: firstly, to be able to estimate the behavior and fate of the oil in order to assess the potential exposure time over which adverse effects to the environment and human uses may exist; and secondly, to evaluate the potential benefits and tradeoffs of various treatment options, including the enhancement of oil translocation processes, to accelerate environmental recovery and restore human use activities.

* Corresponding author. Tel.: +1 2063693679.

E-mail address: ed@owenscoastal.com (E. Owens).

ISSN: 2663-6859 print/2663-6867 online

(C) 2021 ISEIS All rights reserved. doi:10.3808/jeil.202100053
Oil spilled on water is exposed to radiation (light), microbes and oxygen and, for the most part, enters a dynamic environment in which waves and currents impart physical energy to a slick (NRC, 2003; Hazen et al., 2016). Oil deposited on a shoreline may or may not be stranded in the zone affected by waves, tides or currents so that the relative importance of the transformation and translocation processes and pathways differ significantly as compared to oil spilled to water or oil spilled onto the land (Owens, 1978). Critical information for understanding the behavior and fate of stranded oil includes: (a) the relevant chemical and physical properties of the oil; and (b) the amount of oil that makes contact with or is deposited on a shoreline. In addition, it is important to understand: (c) the character of the shore-zone substrate; (d) the ambient environmental conditions (air and water temperature; physical shoreline processes such as winds, waves, tides and ice; floral, faunal and microbial populations, etc.); and (e) the location of the stranded oil with respect to the physical shoreline processes. The combination of these characteristics and processes determines oil behavior in terms of oil loading, penetration, remobilization, retention and persistence, as well as transformation and translo- 


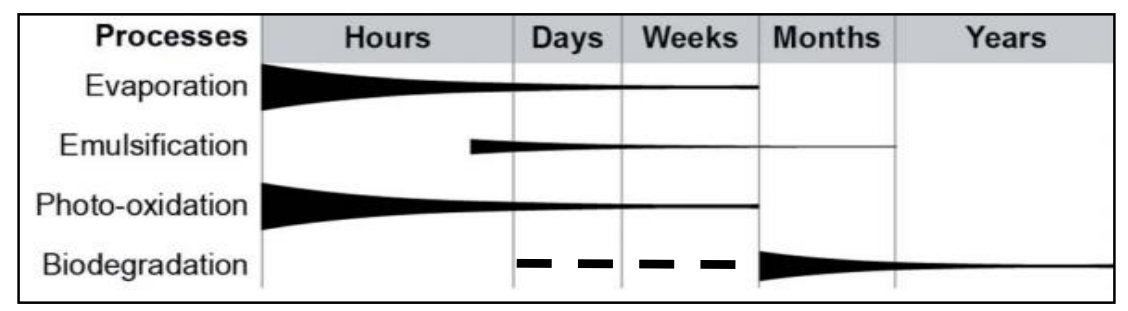

Figure 1. Relative magnitude of weathering process versus elapsed time for floating surface oil following a marine spill (modified from Ward and Overton, 2020).

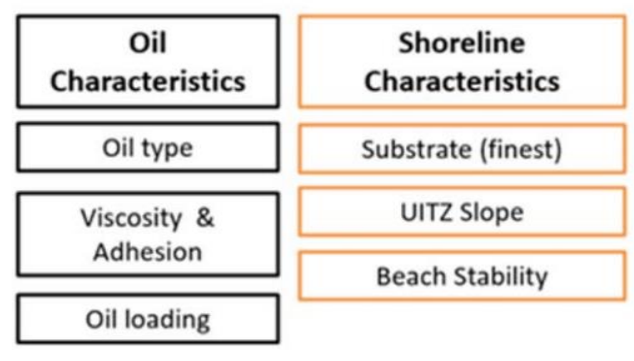

Figure 2. Summary of input parameters for a stranded oil attenuation model (from Taylor et al., 2021). cation. This is a complex relationship that varies in time and space. Importantly, in terms of decision-making for oil spill response operations, some of these pathways may involve interactive biological, chemical and physical processes that may require explanation in a manner that is comprehendible by the full range of disciplinary practitioners as well as non-technical users who would need to understand the persistence and fate of oil stranded on shorelines.

The traditional approach to describing oil weathering and attenuation typically involves dealing with each process separately and assigning relative magnitudes that change through time in relation to each other (Figure 1) (NRC, 2003; Ward and Overton, 2020). This concept for oil weathering on water describes a mixture of physical (for example, advection, dispersion, dissolution, emulsification, evaporation, sedimentation, and spreading) and chemical (biodegradation and photolysis) processes. Models are basically educated guesses based on sound scientific and/or engineering principles using best available data to account for some of the processes involved in the behavior and fate of stranded oil. Some models deal with only one aspect of the overall process/pathway conceptual model and many composite fate models focus largely on surface oil slicks (NRC, 2003).

There are many models that describe and attempt to predict oil transport, behavior and fate in the marine environment (NRC, 2003; Spaulding, 2017) to the extent that a review conducted 25 years ago cited more than 50 composite oil slick models alone at that time (ASCE, 1996). By comparison, only a handful of numerical models have been developed for oil on shorelines (Taylor et al., 2021).

The behavior and fate of oil on freshwater and marine shorelines has been less well studied and is less well understood than oil in the sea. In addition to the exposure of the oil to light, microbes and oxygen, shorelines are physically dynamic environments. Importantly, beach environments are very complex as sediments are often in continuous motion due to hydrodynamic (wave and tidal) processes (Zhao et al., 2016). Knowledge gaps exist with respect to the relative importance of some of the interactive components associated with incident and edge wave interaction in the surf and swash zones, to the point that some have the opinion that we may never fully understand the exact morphodynamics of beach sediment systems (A. J. Bowen, 1974, personal communication, June). No shoreline oil spill models, for example, take into account subharmonic and infragravity oscillations (Guza and Davis, 1974; Huntly and Bowen, 1975) that result in dynamic submarine bars (Lau and Travis, 1973), swash zone cusps or reflective and dissipative beach dynamics (Wright and Short, 1984). The model presented in this discussion is radical as it attempts to simplify this complexity into the few critical and dominant parameters that then can be used to develop a meaningful model to support the oil spill response decision process.

The approach taken in this review is to consider the natural weathering (attenuation) processes that physically or chemically change (transform) stranded oil and the pathways that move or transport (translocate) that oil into the atmosphere or the marine environment. The purpose of this paper is to present a conceptual qualitative model to assist in understanding the behavior and fate of stranded oil and subsequently to evaluate the potential for intervention actions to accelerate ecological recovery and restore human use activities. This conceptual model of the weathering (transformation), natural attenuation and transloca- 
tion of oil on marine shorelines is intended to provide the first order basis for a Shoreline Response Program (SRP) Decision Support Tool under a multi-disciplinary research program on oil translocation that is being developed by the Multi Partner Research Initiative (MPRI) within the Oceans Protection Plan (OPP) of the Federal Government of Canada (Owens et al., 2021). The model is not all-inclusive as it focuses on the dominant processes as they relate to the natural attenuation of stranded oil and does not consider many of the small-scale processes that are locally important, such as wave shear stress (Wilson et al., 2014), the effects of groundwater on subsurface oil in beaches (Boufadel et al., 2019) or local heterogeneities within a specific portion of a shoreline (Geng et al., 2015, 2020).

\section{The Behaviour and Ultimate Fate of Stranded Oil}

Oil that is deposited on a shoreline, whether initially spilled on land or at sea, is only eliminated or removed from the environment through biodegradation, photodegradation, or pyrolysis. All three processes are associated with chemical changes that involve oxygen, although biodegradation can occur in anaerobic environments (e.g., Ghattas et al., 2017). In aerobic marine environments most of the hydrocarbons in oil dispersed within the ocean are degraded with a halflife of days to months, whereas rates are much lower for oil stranded within shorelines. Reasons for the slower degradation rates reflect aspects such as the typically greater concentrations of stranded oil with a lower exposed surface area to oil volume ratio, and exposure to waters with lower nutrient levels compared to offshore waters (Hazen et al., 2016). In certain situations, oil may not fully degrade for very long time periods, or even at all, if it is isolated or sequestered and has minimal contact with oxygen and light (e.g., in asphalt pavements or buried by marine or river sediments) (Reddy et al., 2002; Owens and Sergy, 2005; Owens et al., 2008; Taylor and Reimer, 2008; Hayes et al., 2010; Page et al., 2013). The persistence of stranded oil is typically in the range of days to months and very occasionally years at most, so that these examples of multi-decade persistence are extremely rare in the larger picture of the frequency of stranded oil events.

A wide range of factors affect the behavior of stranded oil (Figure 2) and understanding the interrelationships between all of the interactive processes and pathways is particularly difficult on beaches with highly mobile or highly permeable sediments. Nevertheless, there exists a sufficient level of understanding to develop models or tools to explain the primary processes that are at work and the pathways that oils follow as they are naturally removed from shorelines. One important aspect of oil behavior on beaches relates to penetration, retention and attenuation, and models for this topic are reviewed separately in this Special Issue (Taylor et al., 2021).

Natural oil dispersion has been long recognized as an important process during weathering but the importance of the combination of oil and fine sediments with seawater in the removal of stranded oil was not fully recognized until the early 1990s (Bragg and Yang, 1995). Due to differences in experimental objectives and design, over the intervening years oil- fine particle aggregates have been described variously as clayoil flocs (COF), oil-mineral aggregates (OMA), oil-sediment aggregates (OSA), oil-particle aggregates (OPA) and marine oil snow (MOS), which to some degree confused understanding the significance of the processes. To address this issue, Boglaienko and Tansel (2018) offered a set of terms intended to "clarify the major differences among the different types of aggregates", notably distinguishing between oil-colloidal particle aggregates (OcPA) and oil-granular aggregates (OgPA) (Table 1). Similarly, Gustitus and Clement (2017) recommended a uniform nomenclature based on the physical size (microscopic versus macroscopic) of the aggregates. The two reviews offer slightly different, but not inconsistent, nomenclature and are in agreement that there exists a clear distinction between the processes associated with OcPA "microscopic aggregates $(<0.5 \mu \mathrm{m})$ " versus OgPA “macroscopic agglomerates $(>1 \mathrm{~mm})$ ". A similar distinction was made by Zhao et al. (2016) who defined "oil in suspended OPAs" and "oil in negatively buoyant OPAs".

The range of weathering or attenuation processes, such as, advection, dispersion, dissolution, emulsification, evaporation, flocculation, mineral aggregation, sedimentation and spreading, result in changes in the chemical and physical properties of stranded oil (including adhesiveness, composition, density, specific gravity, surface tension and viscosity) and are an important part of understanding the behavior, transformation and translocation (transport) of stranded oil. Spilled oils, or petroleum hydrocarbons from natural seeps, are ultimately removed from the environment only when they have been chemically transformed to other non-hydrocarbon compounds through biodegradation, photodegradation, or pyrolysis. The simplified model presented in this discussion describes the processes and pathways to this ultimate fate.

\subsection{Biodegradation}

Biodegradation of stranded oil is the natural attenuation by microbial activity, in particular bacteria, and typically requires aerobic conditions and water (Atlas, 1981; Prince et al., 1998, 2003, 2017; Atlas and Bragg, 2013; Hazen et al., 2016). Microbes use petroleum hydrocarbons as a food source and create an oxidized compound. Biodegradation can take place on exposed oil surfaces and is a natural "waste management process" that can be concurrent with the transport processes of dissolution and dispersion of the oil into an aqueous (water) environment. The rate of biodegradation is primarily a function of the available exposed surface oil area, the oil composition, air and water temperature, as well as the availability of nutrients and of oil-degrading microorganisms. Although temperature is a control on rates of biodegradation, the process can be a major fate of spilled crude oil even on polar shorelines (Prince et al., 2002).

Not every component of a hydrocarbon compound may be biodegradable. Constituents such as asphaltenes, polar molecules, resins and other metabolic byproducts including some non-hydrocarbon residues may persist. Fortunately, as these are typically high-molecular weight compounds that are not readily bioavailable, their presence usually is not an environmental concern (Prince et al., 2003). 
Table 1. Oil-sediment Particle Terminology

\begin{tabular}{|c|c|}
\hline After Boglaienko and Tansel 2018 & After Gustitus and Clement 2017 \\
\hline \multicolumn{2}{|c|}{ Microscale or Microscopic Oil-Sediment Aggregates/Residues } \\
\hline $\begin{array}{l}\text { Oil-colloidal Particle Aggregates - OcPA } \\
\circ \quad \text { Contain silts, Clays and/or Colloids }(<50 \mu \mathrm{m}) \\
\circ \quad \text { Settling Velocity 1-553 m/day } \\
\text { - } 0.1 \text { to } 2 \mu \mathrm{m} \text { : Micro Entrained Oil Droplets } \\
\text { - } 2 \text { to } 100 \mu \mathrm{m} \text { Macro Entrained Oil Droplets }\end{array}$ & $\begin{array}{l}\text { Oil Particle Aggregates - OPA } \\
\circ \text { Exclusively organic: Marine Oil Snow (MOS) } \\
\circ \text { Exclusively inorganic: Oil Mineral Aggregate (OMA) }\end{array}$ \\
\hline \multicolumn{2}{|c|}{ Macroscale or Macroscopic Oil-Sediment Aggregates/Residues } \\
\hline $\begin{array}{l}\text { Oil-granular Particle Aggregates - OgPA } \\
\text { - } \quad \text { Sands and Coarser Sediment }>1 \mathrm{~mm} \\
\text { - } \quad \text { settling velocity } 2600 \sim 8640 \mathrm{~m} / \text { day } \\
\end{array}$ & $\begin{array}{l}\text { - } 1 \mathrm{~mm} \sim 10 \mathrm{~cm} \text { Sediment Oil Agglomerate - SOA } \\
\text { - } 10 \mathrm{~cm} \sim 1 \mathrm{~m} \text { Sediment Oil Patty - SOP } \\
\text { - }>1 \mathrm{~m} \text { Sediment Oil Mat - SOM }\end{array}$ \\
\hline
\end{tabular}

Table 2. Primary Weathering Processes and Transport Pathways by Which Oil is Removed from a Shoreline

\begin{tabular}{|c|c|c|}
\hline Oil Weathering Process & Translocation Pathway & Features \\
\hline \multirow[t]{2}{*}{$\begin{array}{l}\text { Volatilization } \\
\text { (Figure 3) }\end{array}$} & $\begin{array}{l}\text { Evaporation } \\
\text { Shoreline - Air }\end{array}$ & $\begin{array}{l}\text { Volatilization and dispersion as small compounds vaporize from a liquid } \\
\text { to a gas phase; airborne particles may be photooxidized or deposited on } \\
\text { land or sea by precipitation where the oil can be biodegraded and further } \\
\text { photooxidized. }\end{array}$ \\
\hline & $\begin{array}{l}\text { Dissolution } \\
\text { Shoreline - Water }\end{array}$ & $\begin{array}{l}\text { Volatilization as water-soluble fractions of the oil rapidly dissolve into } \\
\text { the water body. }\end{array}$ \\
\hline $\begin{array}{l}\text { Chemical Break Down and Physical } \\
\text { Disintegration-Dispersion by } \\
\text { Waves/Currents (Figure } 4 \text { ) }\end{array}$ & Shoreline - Water & $\begin{array}{l}\text { Stranded oil can be chemically broken down by biodegradation or } \\
\text { photodegradation or be eroded, disintegrated, flushed and dispersed by } \\
\text { wave and/or current action to the adjacent water body. }\end{array}$ \\
\hline $\begin{array}{l}\text { Buoyancy Partitioning-Dispersion } \\
\text { (Figure 5) }\end{array}$ & Shoreline - Water & $\begin{array}{l}\text { Physical partitioning as free or adhered oil on a shoreline is remobilized } \\
\text { floated, rinsed and dispersed to the adjacent water body by water motion } \\
\text { and does not require wave or current energy. Buoyant oil-water-fine } \\
\text { sediment aggregates (OcPA - Table } 1) \text { can form in the presence of fine } \\
\text { sediments }(<0.5 \mathrm{~mm})\end{array}$ \\
\hline $\begin{array}{l}\text { In-Situ Transformation } \\
\text { (Figure 6) }\end{array}$ & No Translocation & $\begin{array}{l}\text { The exposed surfaces of the oil are directly biodegraded or } \\
\text { photodegraded in place without physical transfer from one environment } \\
\text { to another. }\end{array}$ \\
\hline
\end{tabular}

\subsection{Photodegradation}

Photodegradation of oil stranded on shorelines is a chemical process that can take place at the air/oil interface for airborne particles or at exposed oil surfaces. The saturated compounds in hydrocarbons are resistant, but the aromatic compounds are particularly sensitive to photodegradation so that these transformation processes are distinctly different from biodegradation in which the larger and more substituted compounds are more resistant to degradation (Garrett et al., 1998). Photooxidation can lead to the formation of a hard surface crust, or asphalt layer, for heavy or weathered oils on beaches, which may then limit the potential for in situ biodegradation, physical removal by wave action, and buoyancy partitioning (Prince et al., 2003). Photodissolution is a sunlight-induced chemical partitioning that forms organic compounds which progress from the oil phase, to the interfacial phase and then to the aqueous phase (Zito et al., 2020).

\subsection{Thermal Degradation}

Thermal degradation (pyrolysis or combustion) involves the burning or incineration of oil and is extremely rare in nature as oil does not spontaneously combust. Condensate and light products or crudes may have low flash points but nevertheless require an ignition source. Ignition sources include lightening, a possible but low probability natural scenario (Superior, undated), but more commonly originate from intentional or unintentional human activities.

\section{Physical Partitioning and Attenuation}

The three physical partitioning processes and the associated pathways by which oil may be removed from shorelines all involve translocation (movement) from one environment to another (Table 2). The fourth weathering process of In-Situ Transformation does not involve translocation. This physical partitioning is a function of the balance between cohesion (the electrical forces that bind molecules of an oil to each other) and adhesion (the electrical forces that attract a molecule of oil to a different substance). Many studies and field experience have shown that for light and medium oils, typically between 50 and $90 \%$ of oil stranded on shorelines is removed through evaporation, dissolution, physical breakdown, and buoyancy within the first 24 to 48 hours (Owens et al., 2008).

The elimination of stranded oil by the transformation from a hydrocarbon to a non-hydrocarbon, however, is only achieved during attenuation through chemical processes associated with biodegradation or photodegradation acting on exposed oil sur- 
faces. Biodegradation and photodegradation can take place where oil is directly exposed, respectively, to water and light (Figure 4). These chemical transformation processes can take place during translocation associated with physical disintegration (Section 3.2) or partitioning (Section 3.3) followed by transportation or dispersion, or in situ by direct biodegradation or photodegradation on exposed surfaces without movement or transfer of the oil (Section 3.4).

\subsection{Volatilization: Evaporation and Dissolution}

Evaporation is the volatilization and physical dispersion of light hydrocarbon fractions into an atmospheric (air) environment without altering the chemical composition of these compounds (Ward and Overton, 2020). Typically, this is a rapid process and rates of evaporation primarily are a function of the available exposed surface area, oil composition, oil/air interface wind velocity, and air temperature. Evaporation is a partitioning pathway that can promote photooxidation in the atmosphere or may lead to subsequent deposition during precipitation events on land or water surfaces where the hydrocarbon molecules may be exposed to microbial degradation and further photooxidation (Figure 3).

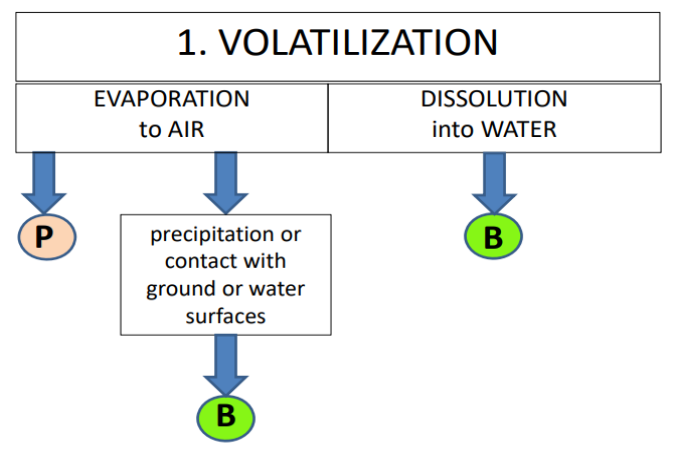

Figure 3. Volatilization process pathways (B -Biodegradation; $\mathrm{P}$ - Photodegradation).

Dissolution is the volatilization of the water-associated or water-soluble fractions of the oil into water and typically is limited to the low-molecular weight hydrocarbons again without altering the chemical composition of these compounds. One form of dissolution is photodissolution which is a sunlightinduced chemical partitioning that forms organic compounds that progress from the oil phase, to the interfacial phase and then to the aqueous phase (Zito et al., 2020). As with evaporation, dissolution is typically a rapid process and the dissolved light compounds are then diluted and susceptible to biodegradation in an aqueous environment.

\subsection{Physical Disintegration and Dispersion}

The physical break down of stranded oil followed by transport and dispersion into an adjacent aqueous (water) envronment is primarily a function of location of the oil on a shoreline with respect to wave energy, tidal exposure, internal cohe- sion of the oil, and the adhesive properties of the oil (Owens, 1985). The physical component of this relationship can be described in terms of three coastal environments:

- Level 1: a shoreline where waves and/or tides provide sufficient energy to move and redistribute sediments; with the result that the stranded oil is disintegrated and dispersed into the aqueous environment by erosion, abrasion, and/or washing;

- Level 2: a shoreline environment in which there is insufficient energy to move the sediments but sufficient energy to erode or wash the stranded oil from the substrate (which may include lifting or buoyancy partitioning of the oil);

- Level 3: a shoreline where there is insufficient energy to move the sediments or the oil so that buoyancy partitioning is the only translocation process; the oil may be released by processes associated with microscopic aggregates (Table 1) or weathered in place through biodegradation or photodegradation.

These three physical energy-based conditions typically vary with time on coasts with locally-generated wind waves and where the tidal range varies significantly during the monthly and annual sun/lunar cycles. For example, oil stranded during an equinoctial spring tide may be above the limit of wave action until either a storm event raises the water level or until the next equinoctial high-water level.

There are two potential pathways for translocation and transformation during or following physical disintegration (erosion or abrasion) or washing by waves, tides or currents (Figure 4):

- Release of small oil particles or droplets to the water or the formation of "microscopic fine-particle oil-sediment aggregates" (OcPAs-Table 1) at exposed water/oil interfaces by wave or current action; these particles then are transported to the adjacent water body and subject to biodegradation at exposed water/aggregate interfaces or to photodegradation at exposed air/aggregate interfaces.

- Release of large oil residues to the water or the formation of "macroscopic oil residue-sediment agglomerates" (OgPAs-Table 1) by mechanical or hydrodynamic oil-sediment mixing with sediments $>1 \mathrm{~mm}$ diameter primarily by wave action; these agglomerates then are transported to the adjacent water body and subject to biodegradation at exposed water/aggregate interfaces or photodegradation at exposed air/aggregate interfaces, or they can settle to the sea bed and there be biodegraded.

The rate of attenuation through dispersion is primarily a function of the available exposed surface area of the oil, salinity, the physio-chemical properties of the oil, and the concentration and properties of the available fine sediments. Importantly, the different oil-particle interactions result in very different oil weathering rates and affect oil persistence and exposure times. The formation of microscopic particles (OcPA) greatly increases the exposed surface area to oil volume ratio, which facilitates dispersion and biodegradation, whereas the formation of macroscopic agglomerates (OgPA) inhibits biodegradation (Gustitus and Clement, 2017). 


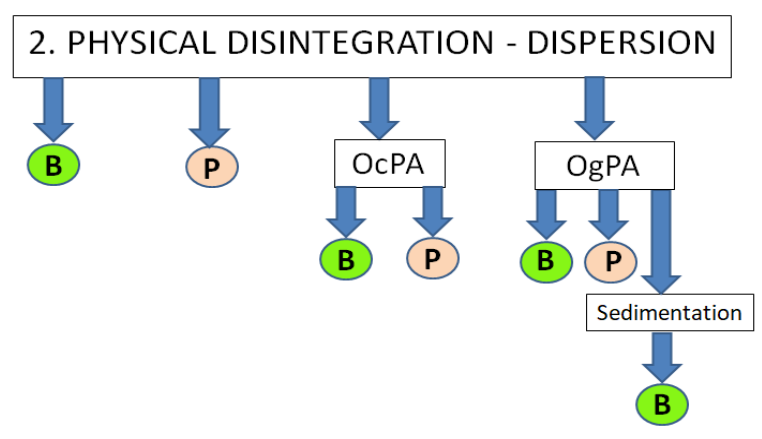

Figure 4. Physical disintegration and dispersion process pathways (B - Biodegradation; $\mathrm{P}$ - Photodegradation).

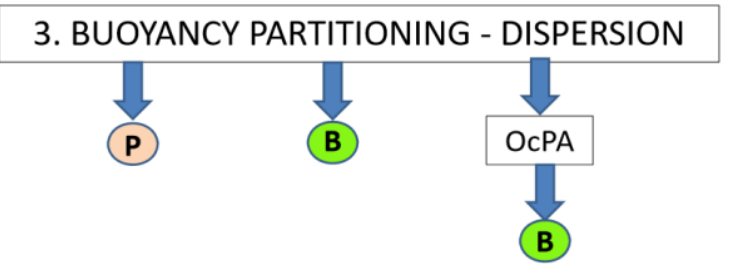

Figure 5. Buoyancy partitioning and dispersion process pathways (B - Biodegradation; $\mathrm{P}$ - Photodegradation).

OcPAs can form in place, without translocation, as entrained free oil droplets. Dispersion of OcPAs can take place due to buoyancy and/or water motion as the oil-sediment particle breaks free from the oil surface. This can be a direct final fate pathway to biodegradation. OgPAs, by contrast, originate as a result of the physical activity of waves and currents at the shoreline and are dispersed initially during that process.

The rate of physical break down varies in time and space and the primary controls are summarized in Table 3. Light oils, such as a diesel product, deposited in the upper intertidal zone on exposed coasts with high wave energy levels may have a half-life of several hours. Oil deposited above the limit of normal wave action may be in a non-marine environment for extensive periods; for example, oil stranded during the quarterly equinoctial spring high tide cycle may not be subject to potential wave action until the next period of similar high water levels three months later, as was the case following the Exxon Valdez spill in 1989 (Owens et al., 1991; Boehm et al., 2008). Medium crude oil or unweathered crude may easily break down but would be protected from wave action and dispersion if buried, a common situation following the Deepwater Horizon incident as stranded oil was frequently buried by the normal postwinter buildup of sand on the northern Gulf of Mexico beaches (Owens et al., 2011).

\subsection{Buoyancy Partitioning and Dispersion}

Physical remobilization (refloating) and translocation (dispersion) into an adjacent aqueous (water) environment can take place in the absence of waves and currents if the cohesion and adhesion forces of the oil are overcome by the upward buoyancy forces in the water. A primary factor affecting the rate of buoyancy partitioning is the location of the oil on the shoreline and exposure to changing water levels. Following partitioning and dispersion there are three pathways to degradation and transformation; two of these are chemical break down processes and the third involves the formation of OcPAs (Table 1) followed by biodegradation (Figure 5).

Several studies have shown that a high portion of stranded oil is refloated within a few tidal cycles of deposition. Almost $60 \%$ of an unweathered Lago Medio medium crude oil stranded on a mixed coarse-sediment beach during the Baffin Island Oil Spill (BIOS) experiment study was remobilized and not redeposited at the site in the first 24 hours (Owens et al., 2008). The site is a very sheltered, very low wave energy location in which physical disintegration of the oil was not a significant process. An additional $7.5 \%$ of the oil applied was removed naturally over the following 27 days. During the Svalbard field experiments the three mixed-sediment untreated plots, each oiled with 2200 L of an Intermediate Fuel Oil (IFO 30; API gravity 18.3), showed an initial rapid oil removal. The BIOS and the Svalbard study shorelines were both sheltered, very low wave-energy environments during the two-month study periods at these locations. At Site $2 \mathrm{~S}$ on Svalbard, during the calm conditions of the first high tide, approximately $300 \mathrm{~L}$ was recovered and $150 \mathrm{~L}$ of oil was observed on the water surface, for a first tidal cycle removal through buoyancy partitioning on the order of $21 \%$ (Owens et al., 2003). Table 4 provides a re-analysis of the sample data results from the Svalbard field experiments presented by Owens et al. (2003) to show the changes through time from the initial oiling. Oil was deposited in the upper intertidal zone at Sites 1 and 2, which were very sheltered wave-energy locations. Site 3 had slightly higher wave energy levels than the other two locations, but still a very low wave-energy environment in a fjord, and the oil was deposited in the upper and supratidal zones so that approximately half of that area was above the limit of wave action during the study period.

\subsection{In Situ Biodegradation and Photodegradation}

Biodegradation and photodegradation can take place where oil is directly exposed, respectively, to water and light These transformation processes can take place in situ (Figure 6), without movement or transfer of the oil, or during translocation associated with partitioning and transportation or dispersion (Section 3.2). A long-term study on an Arctic beach indicates that residual stranded oil that is not removed by physical transport will likely be eventually biodegraded, albeit at a slow rate due to low temperatures and the limited availability of trace nutrients (Prince et al., 2002).

Figure 7 provides an example of in situ biodegradation and photooxidation using chromatograms for the original cargo oil spilled from the T/V Arrow in 1970 and for five samples collected at a single shoreline location in 2005 (Owens et al., 2008). The most biodegraded and photooxidized samples were those collected from the surface of asphalt pavements in an upper intertidal zone (UITZ) and a mid-tide location (samples D1 and $B$ in Figure 7). The reduction in the extent of degradation for a sub-surface sample recovered from "within" the above UITZ 
Table 3. Primary Controls on the Rate of Physical Break down of Stranded Oil

\begin{tabular}{|c|c|c|}
\hline & $\begin{array}{l}\text { Factors that Favor Higher Rates of Break Down and } \\
\text { Reduce Persistence Times }\end{array}$ & $\begin{array}{l}\text { Factors that Reduce Rates of Break Down and Increase } \\
\text { Persistence Times }\end{array}$ \\
\hline $\begin{array}{l}\text { Oil Volume and } \\
\text { Character }\end{array}$ & $\begin{array}{l}\text { Lighter and unweathered oils are less cohesive, } \\
\text { break down more rapidly and typically have a } \\
\text { larger fraction that is dissolvable. } \\
\text { Light loadings have high surface area to volume } \\
\text { ratios and a higher proportion of the stranded oil } \\
\text { is exposed to biodegradation and } \\
\text { photodegradation. }\end{array}$ & $\begin{array}{l}\text { Heavy oils, weathered oils and oil-sediment asphalt } \\
\text { pavements are more cohesive and more resistant to } \\
\text { break down. } \\
\text { - Higher oil loadings have relatively low surface area } \\
\text { to volume ratios that require more time and/or } \\
\text { energy to break down. }\end{array}$ \\
\hline $\begin{array}{l}\text { Physical Energy } \\
\text { Available }\end{array}$ & $\begin{array}{l}\text { Wave energy is a function of wave height; larger } \\
\text { waves have high levels of mechanical and } \\
\text { hydraulic energy that promote break down. } \\
\text { Wave energy is concentrated in a narrower band } \\
\text { on shores with a small tidal range. }\end{array}$ & $\begin{array}{l}\text { Lower wave heights provide less hydraulic and } \\
\text { mechanical physical energy for break down. } \\
\text { - Large tidal range dissipates available wave energy } \\
\text { over a wide beach area. } \\
\text { - Shore zone ice can sequester oil from wave action. }\end{array}$ \\
\hline $\begin{array}{l}\text { Location of The } \\
\text { Oil }\end{array}$ & $\begin{array}{l}\text { - Surface oil in the intertidal zone has the greatest } \\
\text { exposure times for wave contact. }\end{array}$ & $\begin{array}{l}\text { - Contact time and exposure to break down is lower } \\
\text { for oil deposited above the mean high tide level. } \\
\text { Oil that penetrates sediments or is buried during } \\
\text { beach sediment cycles may be sheltered from direct } \\
\text { exposure to mechanical or physical energy for } \\
\text { extended time periods and biodegrade only slowly } \\
\text { if in an anaerobic environment. }\end{array}$ \\
\hline
\end{tabular}

Table 4. Initial and Subsequent Removal of IFO 30 from Untreated Shoreline Plots (\% Reduction)

\begin{tabular}{|c|c|c|c|c|}
\hline & \multirow[t]{2}{*}{ Oil Loading $\left(\mathrm{L} / \mathrm{m}^{2}\right)$} & \multicolumn{3}{|c|}{ Removal - Reduction from Original Loading (\%) } \\
\hline & & First Sample Data & Intermediate Data Set & After 2 Months \\
\hline Site 1 & 7.5 & $46 \%$ in 6 days & $92 \%$ in 11 days & $98 \%$ \\
\hline Site $2 \mathrm{~S}$ & 5 & $62 \%$ in 8 days & $64 \%$ in 13 days & $96 \%$ \\
\hline Site 3 & 10 & $36 \%$ in 5 days & $32 \%$ in 10 days & $38 \%$ \\
\hline
\end{tabular}

surface-asphalt pavement (sample D2) clearly illustrates the influence of photooxidation and formation of a protective surface crust (or asphalt layer) that diminished in situ biodegradation rates, physical removal by wave action, and buoyancy partitioning. Although the pore spaces at location $\mathrm{C}$ (oil recovered from beneath a boulder) appeared to be completely filled with oil (oil saturated), the evidence of oil biodegradation indicated that the sample was not impervious to the flow of interstitial waters. The least weathered sample (A) was collected from an oil deposit that was sequestered just above a fine sediment layer, which limited the flow of interstitial waters and the availability of oxygen, and that appeared to have been naturally exhumed by a storm event just prior to sampling.

\section{Geographically Variable Shoreline Environmental Factors}

Weathering processes and rates of attenuation are dependent on the character and loading of oil on the shoreline and the environmental setting, which includes a wide range of site-specific physical (coastal meteorology-oceanography, shoreline substrate material) and coastal ecological (nutrient availability, microbial population) parameters. The oil character and loading are incident specific and depend on how much oil was spilled, where the oil was spilled and transport to the shoreline, and any weathering that takes place prior to deposition on a shoreline. The shoreline character and environmental parameters can be predetermined at a regional level (Figure 2) and preloaded into an attenuation model for stranded oil (Owens et al., 2021). Where full data sets are not available categorization enables the regional character to be input; for example, tidal range, wave energy, storm frequency, coastal suspended sediment loads, etc. Some parameters, such as the number of day-light hours available for operations, can be calculated for all shoreline locations for any date. Dynamic environmental information (winds, wave energy, ice formation, temperature, etc.) can be organized by month or season for most uses and scenarios or can be set up to provide synoptic data.

In the process of developing a stranded oil attenuation model for Canada, data were not found to exist for all of the shoreline input parameters for all $250,000 \mathrm{~km}$ of Canada's marine coasts. For example, there is not a full data set for the average or earliest and latest dates for intertidal ice formation and decay, which is a critical factor in oil behavior and attenuation at the local scale on all coasts except for most Pacific Ocean shorelines. However, a regional approximation based on $50 \mathrm{~km}$ scale grids (Owens et al., 2021) can be developed using longterm data on first and last frosts and the number of frost days from the web-based Climate Atlas of Canada (The Climate Atlas of Canada, 2020). Similarly, although the coverage of tide stations throughout Canada is sparse in many areas, particularly on Arctic coasts, extrapolation provides a sufficient level of accuracy for model and scenario development.

In the real world of coastal environments a few parameters 
Table 5. Intertidal Shoreline Types and Implications for Stranded Oil (ECCC 2018)

\begin{tabular}{|c|c|}
\hline \multicolumn{2}{|l|}{ Impermeable Substrates } \\
\hline Bedrock & $\begin{array}{l}\text { Impermeable native rock, including cliffs, stacks, ramps, terraces, platforms and reefs. No oil } \\
\text { penetration. }\end{array}$ \\
\hline Ice & $\begin{array}{l}\text { Ice that occurs where glaciers or ice shelves reach the coast, permafrost is exposed, or solid seasonal ice } \\
\text { forms as a layer on the shore. No oil penetration. }\end{array}$ \\
\hline Man-Made Impermeable & $\begin{array}{l}\text { Manmade (anthropogenic) structures that are composed of impermeable materials in a form that oil } \\
\text { penetration is not an issue. }\end{array}$ \\
\hline \multicolumn{2}{|l|}{ Permeable Substrates } \\
\hline Manmade Permeable & $\begin{array}{l}\text { Manmade (anthropogenic) features and structures that are composed of permeable material(s), either of } \\
\text { natural or manmade origin (e.g., concrete). Man-made permeable shore-lines may be considered the } \\
\text { equivalent of similar sized natural sediments (e.g., rip-rap = man-made/ boulder; which has a high } \\
\text { potential for oil penetration, low retention). }\end{array}$ \\
\hline Sand Beach & $\begin{array}{l}\text { Beach composed of sand. May include small amounts }(<10 \%) \text { of granules, silt, and clays. Limited } \\
\text { penetration potential except for light oil products: high potential for burial by sand transport. }\end{array}$ \\
\hline $\begin{array}{l}\text { Mixed Sediment (Sand-Peb-ble- } \\
\text { Cobble) Beach }\end{array}$ & $\begin{array}{l}\text { Sand mixed with any combination of coarse sediments, such as granules, pebbles and cobbles. Limited } \\
\text { penetration potential except for light oil products as pore spaces are filled with fine-grained sediment. }\end{array}$ \\
\hline Pebble-Cobble Beach & $\begin{array}{l}\text { A beach dominated by either pebbles or cobbles, or a combination of both, typically with }<10 \% \text { sand. } \\
\text { High potential for penetration and retention of all but the most viscous oils. }\end{array}$ \\
\hline Boulder Beach & $\begin{array}{l}\text { A beach dominated by the presence of boulders; may overlay fine materials or bedrock. High potential } \\
\text { for penetration and retention of all but the most viscous oils. }\end{array}$ \\
\hline Mud Flat & $\begin{array}{l}\text { Wide, low-angle intertidal zone consisting of mud, silt and/or clay. Limited penetration po-tential except } \\
\text { for light oil products or where animal burrows are present. }\end{array}$ \\
\hline Sand Flat & $\begin{array}{l}\text { Wide, low-angle intertidal zone consisting of sand; may include granules, silts and clays. Limited } \\
\text { penetration potential except for light oil products: high potential for burial by sand transport. }\end{array}$ \\
\hline Mixed Sediment Flat & $\begin{array}{l}\text { Wide, low-angle intertidal zone consisting of sand plus }>10 \% \text { of any or all of the coarser sedi-ments: } \\
\text { granule, pebble, cobble or boulder. Limited penetration potential except for light oil products. }\end{array}$ \\
\hline Snow-covered Shoreline & $\begin{array}{l}\text { Any shoreline type with seasonal snow that is deposited on top of the substrate. Oil may be partially } \\
\text { adsorbed in snow. }\end{array}$ \\
\hline Wetlands/ Marsh & $\begin{array}{l}\text { Vegetated shoreline that is covered at least once a month by salt or brackish water at spring high tides or } \\
\text { during wind-driven surges. Limited penetration potential into the mineral soils except for light oil } \\
\text { products or where animal burrows are present. }\end{array}$ \\
\hline Peat Shoreline & $\begin{array}{l}\text { Dominated by peat; a spongy, compressible, fibrous material that forms from the incomplete } \\
\text { decomposition of plant materials. Peat readily adsorbs oil. }\end{array}$ \\
\hline Tundra Cliff (Ice Rich) & $\begin{array}{l}\text { Erosional feature composed of a tundra (vegetation) mat that usually overlies peat and has exposed } \\
\text { ground ice (permafrost). Peat readily adsorbs oil. }\end{array}$ \\
\hline Tundra Cliff (Ice Poor) & Eroding, unconsolidated cliffs with a surface tundra mat. Peat readily adsorbs oil. \\
\hline $\begin{array}{l}\text { Inundated Low-Lying Tundra } \\
\text { Shoreline }\end{array}$ & $\begin{array}{l}\text { Low-lying coastal tundra that is flooded or inundated by marine or brackish waters during spring high } \\
\text { tides or wind-driven surges. Limited penetration potential except for light oil pro-ducts or where ice } \\
\text { cracks are present. }\end{array}$ \\
\hline
\end{tabular}

dominate the behavior and fate of stranded oil, in addition to the character of the stranded oil itself. The four parameters that stand out are the level of wave energy, shore zone ice, the shore type, and the availability of fine-grained sediments. Data exist for each of these parameters in a suitable form and in sufficient detail for the scale of the models that support the use of the SRP Decision Support Tool for training and planning.

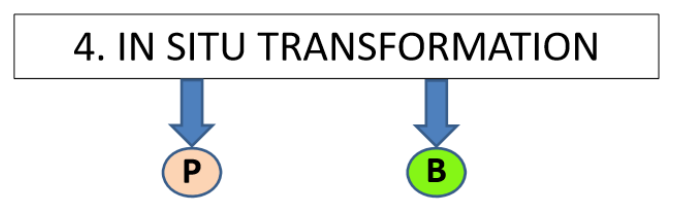

Figure 6. In situ transformation pathways (B - Biodegradation; $\mathrm{P}$ - Photodegradation).

There are a number of slightly different ways to define and group the range and character of shoreline types as described in oil spill manuals, guidelines, and other planning or training documents; although, these are generally consistent with each other (e.g., NOAA, 1992; ECCC, 2018). With respect to the shoreline character and in particular the substrate materials, fortunately, the entire Pacific and Atlantic region and Beaufort Sea coastal shorelines have been mapped in detail for substrate type (Percy, 1993; Howes et al., 1994; Percy et al., 1997; Wynja et al., 2015). The SRP Decision Support Tool currently being developed under the Multi-Partner Research Initiative (MPRI) program uses the intertidal shoreline type categorization scheme established by Environment and Climate Change Canada (ECCC) (Table 5).

There is a sufficient level of similarity within these shore types to characterize the likelihood of the presence of fine sediments (silts and finer) to promote oil-sediment aggregation and translocation as OcPAs at a scale that is appropriate for modeling in the Decision Support Tool. Table 6 presents a Fine Sedi- 


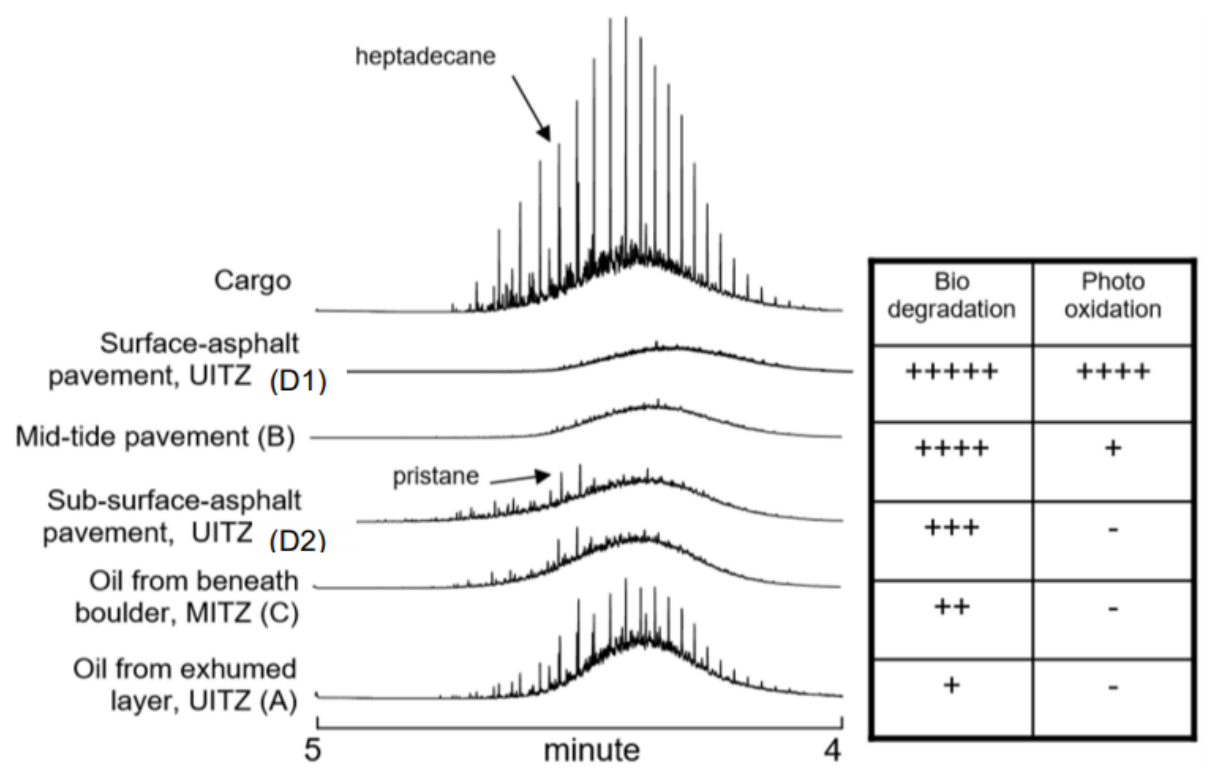

Figure 7. Chromatograms of the "fresh" cargo and weathered spilled oil from shoreline samples collected 35 years after the Arrow spill, ranked according to degree of biodegradation and photooxidation (from Owens et al. 2008).

ment Index developed for the Canadian modeling project to indicate the relative potential for the presence of significant amounts of fines in each of the intertidal shoreline types in Table 5. Bedrock, ice and man-made permeable shore types have negligible sources of fine sediment in the intertidal zone.

Backshore and shore types that may add substantial volumes of fine sediments directly to the shore zone include unresistant, sedimentary bedrock outcrops, such as mudstones and siltstones, and eroding fluvio-glacial deposits, such as till cliffs (Figure 8) and are included in this table. As an example, a volumetric analysis of six till cliff sediment samples in Chedabucto Bay (Nova Scotia, Canada) yielded a value of $37.3 \%$ for the silt/clay fraction (Table 7) and an annual sediment supply rate of $3,509 \mathrm{~m}^{3} /$ year of the silts and clays for a $3.4 \mathrm{~km}$ section of shoreline (Owens and Rashid, 1976).

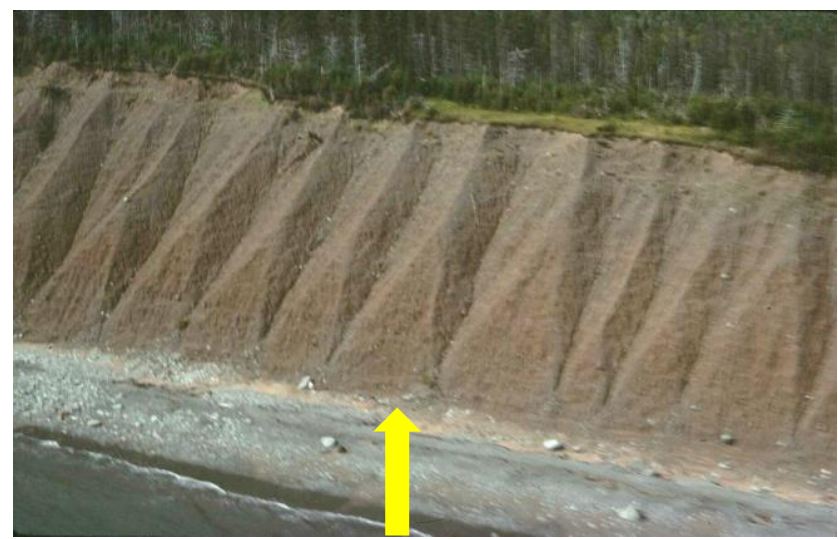

Figure 8. Eroding glacial till cliff with a band of washed off silt-clay sediment (arrow) at the base of the eroding face, Nova Scotia, Canada.

\section{Discussion and Conclusions}

\subsection{Shoreline Attenuation and Oil Fate Knowledge Gaps and Recommendations for Future Studies}

Table 8 summarizes the results of the review and incorporates a broader understanding of the science and literature for shoreline oil natural attenuation and translocation pathways. The symbols $(\Delta+\bullet)$ indicate the degree to which that topic is currently understood based on specific scientific investigations or from real-world experience. Three triangles indicate a high level of confidence $(\Delta \Delta \Delta)$, two crosses indicate an adequate level of confidence (++), and a single dot indicates a basic understanding with room for improvement by future studies $(\bullet)$. The dark shading indicates a relatively poor understanding of the transformation processes and/or translocation pathways; a topic that has a high priority for future studies.

All of the three attenuation "final fate" processes that transform stranded oil to non-hydrocarbon materials (biodegradation, photodegradation and pyrolysis) are well reported in many science-based peer reviewed publications. The current knowledge base is sufficient for the development of the geographic variability model and for the SRP Decision Tool that is currently under development by MPRI scientists (Owens et al., 2021).

The knowledge gap for oil buoyancy and sediment substrates requires a better understanding of the relationship between the adhesive properties of the oil, the hydraulic conductivity of the sediments, and the internal cohesion of the oil. Current MPRI oil translocation studies are underway in the laboratory and a newly designed shoreline mesocosm tank facility to advance the understanding of buoyancy partitioning and, in particular, the role of OcPA in the absence of wave energy. This latter process is primarily a function of the available exposed surface area of the oil deposit, salinity, and the concen- 
Table 6. Fine Sediment Index (FSI) for Shore and Backshore Types

\begin{tabular}{|c|c|c|}
\hline Shore or Backshore Type & Sedimentological Character & FS Index \\
\hline \multicolumn{3}{|l|}{ Impermeable Substrates } \\
\hline Bedrock & No sediment & 0 \\
\hline Ice & Very small amounts $(<10 \%)$ of granules, sands, silts, and clays may be released as the ice melts. & 0 \\
\hline Man-Made Impermeable & Solid surface of concrete, metal wood, etc.; no sediment & 0 \\
\hline \multicolumn{3}{|l|}{ Permeable Substrates } \\
\hline Man-Made Permeable & Refer to the equivalent similar sized natural sediments, e.g., rip-rap $=$ man-made boulder & \\
\hline Sand Beach & Predominantly sand; may include small amounts $(<10 \%)$ of granules, silt, and clays & 7 \\
\hline $\begin{array}{l}\text { Mixed (Sand-Pebble- } \\
\text { Cobble) Beach }\end{array}$ & $\begin{array}{l}\text { Predominantly coarse sediments; may include small amounts }(<10 \%) \text { of granules, sand, silt, and } \\
\text { clays }\end{array}$ & 6 \\
\hline Pebble-Cobble Beach & $\begin{array}{l}\text { Predominantly coarse sediments; may include small amounts }(<10 \%) \text { of granules, sand, silt, and } \\
\text { clays }\end{array}$ & 4 \\
\hline Boulder Beach & $\begin{array}{l}\text { A beach dominated by the presence of boulders; may include small amounts }(<10 \%) \text { of granules, } \\
\text { sand, silt, and clays }\end{array}$ & 3 \\
\hline Mud Flat & Predominant silts and clays with some sand & 10 \\
\hline Sand Flat & Predominantly sand with some granules, silts and clays & 7 \\
\hline Mixed Sediment Flat & $\begin{array}{l}\text { Predominantly sand plus }>10 \% \text { of any or all of the coarser sediments: granule/ } \\
\text { pebble/cobble/boulder and some silts and clays }\end{array}$ & 7 \\
\hline Snow-covered & $\mathrm{n} / \mathrm{a}$ & 0 \\
\hline Wetlands/ Marsh & Predominantly organic material and mineral soils with significant amounts of silts and clays & 9 \\
\hline Peat Shoreline & Dominated by peat; may include small amounts $(<10 \%)$ of sand, silt, and clays & 2 \\
\hline $\begin{array}{l}\text { Inundated Low-Lying } \\
\text { Tundra }\end{array}$ & $\begin{array}{l}\text { Predominantly organic material and mineral soils with potentially significant amounts of silts } \\
\text { and clays }\end{array}$ & 8 \\
\hline Tundra Cliff (Ice Rich) & $\begin{array}{l}\text { Eroding exposed ground ice that contains little sediment but that may include small amounts of } \\
\text { sands, silts and clays }\end{array}$ & 1 \\
\hline Tundra Cliff (Ice Poor) & Eroding tundra with peat over sediment that may include sands, silts and clays & 7 \\
\hline Glacial Till Cliff & Predominantly sands, silts and clays with coarse sediments & 10 \\
\hline
\end{tabular}

*10 = highest potential; $1=$ lowest; $0=$ not applicable

Table 7. Volumetric Analysis (\%) of Till Cliff Samples, Deep Cove, Nova Scotia, Canada (Owens and Rashid 1976)

\begin{tabular}{lllllll}
\hline Boulder & Cobble & Pebble & Granule & Sand & Silt/Clay & Water \\
\hline 6.5 & 6.2 & 12.8 & 3.4 & 15.9 & 37.3 & 17.9 \\
\hline
\end{tabular}

Table 8. Summary of State of Knowledge of Shoreline Oil Attenuation Processes and Pathways

\begin{tabular}{llll}
\hline & $\begin{array}{l}\text { Transformation Process/ } \\
\text { Translocation Pathways }\end{array}$ & $\begin{array}{l}\text { Attenuation and Trans- } \\
\text { location Rates }\end{array}$ & $\begin{array}{l}\text { Supported by Peer Reviewed } \\
\text { Scientific Literature }\end{array}$ \\
\hline Shoreline Oil Transformation & & & $\Delta \Delta \Delta$ \\
Biodegradation & $\Delta \Delta \Delta$ & $\Delta \Delta \Delta$ & $\Delta \Delta \Delta$ \\
Photodegradation & $\Delta \Delta \Delta$ & ++ & $\Delta \Delta \Delta$ \\
$\quad \begin{array}{l}\text { Pyrolysis } \\
\text { Shoreline Translocation Pathways }\end{array}$ & $\Delta \Delta \Delta$ & $\Delta \Delta \Delta$ & $\Delta \Delta \Delta$ \\
$\quad$ Evaporation & $\Delta \Delta \Delta$ & $\Delta \Delta \Delta$ & $\Delta \Delta \Delta$ \\
Physical (wave) energy & $\Delta \Delta \Delta$ & $\Delta \Delta \Delta$ & $\Delta \Delta \Delta$ \\
Buoyancy & & & $\Delta \Delta \Delta$ \\
Fine Sediment Oil (OcPA) Emulsification & ++ & $\bullet$ & ++ \\
In Situ Biodegradation/Photodegradation & $\Delta \Delta \Delta$ & &
\end{tabular}

trations and properties of the available fine sediments. Aggregation by OcPA fines is well reported in many science-based peer reviewed publications but is a topic that is generally not well understood by spill responders and decision-makers, and is not universally accepted. This issue exists, in part, because of a lack of familiarity with the processes of oil-sediment aggregation and physical dispersion into an aqueous (water) environment with or without wave-energy. Research to improve understanding of aggregation in the presence of fine particles would support the demonstrated benefits of in situ treatment of oiled shorelines through sediment mixing or relocation (with or without significant wave-energy).

\subsection{Concluding Remarks}

This review presents an evaluation of the understanding of the processes that act on the stranded oil and the pathways by which oil is transformed into non-hydrocarbon materials. The 
four partitioning processes and the associated pathways by which oil may be removed from shorelines all involve physical dispersion or translocation (movement) from one environment to another. This knowledge is crucial in shoreline response to provide a science-based foundation to develop decisions on whether or not to intervene and physically recover the oil, leave it to Nature (a natural attenuation strategy), and/or to accelerate weathering and attenuation of the residual oil by enhancement of oil translocation processes. In its quest to expand its oil spill response "tool box", Canada has identified oil translocation as a subject matter under its Alternative Response Measure (ARMs) research program under the Multi-Partner Research Initiative pertaining to the evaluation and approval of future oil spill response strategies for oiled shorelines. To support the selection of the optimal spill response option(s) for the remediation of oil spilled on coastal shorelines, this review on oil translocation and attenuation supports the creation of a simulation model for natural attenuation that will provide the core of a SRP Decision Support Tool. This review presents a conceptual model based on our knowledge of oil weathering processes and translocation pathways that is being developed to aid decision-makers, planners, and others responsible for the selection of the most appropriate spill response for use on oiled shorelines. The model has been developed for Canada's marine shorelines but can be readily adapted for all coastal environments world-wide.

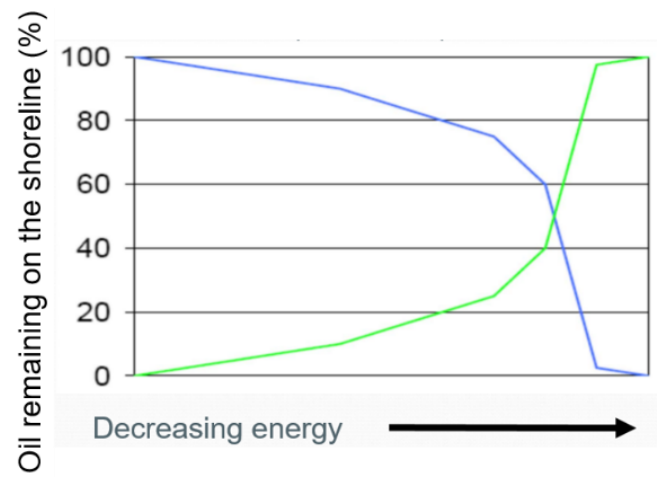

Figure 9. Relative removal (\%) of stranded oil by physical break down (wave energy; blue) and by dispersion and biodegradation associated with OcPAs (green).

The review has highlighted that for the most part, evaporation of the volatile fractions and dissolution of the water soluble fractions of a spilled oil takes place at sea before oil is stranded and thus, they are only a significant attenuation process when oil is spilled directly on the shoreline. In most instances, physical remobilization and dispersion as a result of wave activity is the single most effective and rapid process for the removal of oil from shorelines to the marine environment. Remobilization and buoyancy partitioning take place during physical break down, and field studies have shown that between 30 and $60 \%$ of stranded medium crude and fuel oils can be removed during the first few days even in the absence of wave energy. In situ biodegradation and photodegradation also play roles as all of the attenuation processes can take place at the same time. The traditional approach to assigning relative magnitudes to the weathering and attenuation processes (Figure 1) focuses on oil at sea and does not consider the role of wave action at the shoreline nor include the more recently understood and appreciated role of OcPA that is associated with the dispersion and biodegradation of stranded oils. An empirical model (Figure 9) illustrates the relative contributions of removal of stranded oil by physical wave action versus dispersion by OcPAs as physical wave energy levels at the shoreline decrease.

This empirical model illustrates how the dominant processes change with respect to the physical environment discussed in Section 3.2. When and where waves and/or tides provide sufficient energy for sediment movement then erosion, abrasion and washing processes dominate (Owens, 1978); in the absence of that energy dispersion and biodegradation associated with OcPAs dominate. A numerical model (A-DROP) predicts that the oil volumes associated with oil in suspended OPAs (i.e., OcPAs as defined in Table 1) in nearshore environments varies from zero in the high energy breaker zone to 0.01 $\mathrm{kg} / \mathrm{m}^{3}$ in the swash zone (Zhao et al., 2016).

Understanding the transformation processes and translocation pathways is the basis for estimating the persistence or residence time of stranded oil, and therefore the exposure of and impact on ecological resources and human activities. In turn, this understanding is crucial to the decision process on whether to let Nature take its course or to intervene to remove the oil and/or accelerate the weathering and attenuation processes (based on our improved knowledge of the primary controlling factors) to reduce the expected residence time of the oil.

Acknowledgments. The project forms part of the Contribution Agreement between the MPRI Program of Fisheries and Oceans Canada and Concordia University for the project "Oil Translocation Pathways and Processes in Canadian Shoreline Environments".

\section{References}

ASCE Task Committee on Modeling of Oil Spills. (1996). State-ofthe-art review of modeling transport and fate of oil spills. Journal of Hydraulic Engineering, 122(11), 594-609. https://doi.org/10.1061/ (ASCE)0733-9429(1996)122:11(594)

Atlas, R.M. (1981). Microbial Degradation of Petroleum Hydrocarbons: an Environmental Perspective. Microbiological Reviews, 45(1), 180-209.

Atlas, R.M. and Bragg, J.R. (2013). Removal of Oil from Shorelines: Biodegradation and Bioremediation. Oil in the Environment: Legacies and Lessons of the Exxon Valdez Oil Spill, 176-197.

Boglaienko, D. and Tansel, B. (2018). Classification of Oil-Particle Interactions in Aqueous Environments: Aggregate Types Depending on State of Oil and Particle Characteristics. Marine Pollution Bulletin, 133, 693-700. https://doi.org/10.1016/j.marpolbul.2018. 06.037

Boufadel, M., Geng, X., An, C., Owens, E., Chen, Z., Lee, K., Taylor, E. and Prince, R.C. (2019). Factors affecting the deposition, retention, and biodegradation of oil stranded on beaches. Designing laboratory experiments to capture real-world complexities. Current Pollution Reports, 5(4), 407-423. https://doi.org/10.1007/s40726-01900129-0

Bragg, J.R. and Yang, S.H. (1995). Clay-oil flocculation and its role in natural cleansing in Prince William Sound following the Exxon Valdez oil spill. In Exxon Valdez Oil Spill: fate and effects in 
Alaskan Waters, 178-214. https://doi.org/10.1520/STP19864S

ECCC. (2018). Shoreline Cleanup Assessment Technique (SCAT) Manual-Third Edition. Prepared and provided by Triox Environmental Emergencies, Owens Coastal Consultants, Environ-mental Mapping Ltd., for Environment and Climate Change Canada, Ottawa ON, pp.191.

Garrett, R.M., Pickering, I.J., Haith, C.E. and Prince, R.C. (1998). Photooxidation of Crude Oils. Environmental science \& technology, 32 (23), 3719-3723. https://doi.org/10.1021/es980201r

Geng, X., Boufadel, M.C., Lee, K., Abrams, S. and Suidan, M. (2015). Biodegradation of subsurface oil in a tidally influenced sand beach: Impact of hydraulics and interaction with pore water chemistry. Water Resources Research, 51(5), 3193-3218. https://doi.org/10. 1002/2014WR016870

Geng, X., Boufadel, M.C., Michael, H. A., Heiss, J. W. and Lee, K. (2020). Groundwater flow and moisture dynamics in the swash zone: Effects of heterogeneous hydraulic conductivity and capillarity. Water Resources Research, 56(11), e2020WR028401. https://doi. org/10.1 029/2020WR028401

Gustitus, S.A. and Clement, T.P. (2017). Formation, Fate and Impacts of Microscopic and Macroscopic Oil-Sediment Residues in Nearshore Marine Environments: A Critical Review. Reviews of Geophysics, 55(4), 1130-1157. https://doi.org/10.1002/2017RG000572

Guza, R.T. and Davis, R.E. (1974). Excitation of edge waves by waves incident on a beach. Journal of Geophysical Research, 79(9), 12851291.https://doi.org/10.1029/JC079i009p01285

Hayes, M.O., Michel, J. and Betenbaugh, D.V. (2010). The Intermittently Exposed, Coarse-Grained Gravel Beaches of Prince William Sound, Alaska; Comparison with Open-Ocean Gravel Beaches. Journal of Coastal Research, 26, 4-30. https://doi.org/1 0.2112/081071.1

Hazen, T.C., Prince, R.C. and Mahmoudi, N. (2016). Marine Oil Biodegradation. Environmental Science \& Technology, 50(5), 21212129. https://doi.org/10.1021/acs.est.5b03333

Howes, D.E., Wainwright, P., Baird, R., Berg, L., Cooper, J., Haggarty, J.M., Harper, J.R., Owens, E.H., Reimer, P.D. and Summers. K. (1994). Oil spill response atlas for Southern Strait of Georgia. Environmental Emergency Services, BC Ministry of Environment, Victoria, BC, pp. 317.

Howes, D., Harper, J.R. and Owens, E.H., (1994). Physical Shore Zone Mapping System for British Columbia. Report prepared by Environmental Emergency Services, Ministry of Environment (Victoria, $B C$ ), Coastal and Ocean Resources Inc. (Sidney, BC), and Owens Coastal Consultants (Bainbridge, WA).

Huntly, D.A. and Bowen, A.J. (1975). Field observations of edge waves and their effect on beach material. Journal of the Geological Society, 131(1), 69-81. https://doi.org/10.1144/gsjgs.131.1.0069

Lau, J. and Travis, B. (1973). Slowly varying Stokes waves and submarine longshore bars. Journal of Geophysical Research, 78(21), 4489-4497. https://doi.org/10.1029/JC078i021p04489

NOAA. (1992). Shoreline Countermeasures Manual-Temperate Coastal Environments. Hazardous Materials Response and Assessment Di- vision, Seattle WA, pp. 90. https://response.restoration.noaa. gov/sites/default/files/shoreline_countermeasures_temperate.pdf (accessed 15 January 2021).

NRC. (2003). Oil in the Sea III: Inputs, Fates and Effects. Transportation Research Board and National Research Council, The National Academies Press, Washington DC, pp. 277. https://doi.org/10.1722 6/10388

Owens, E.H. (1978). Mechanical dispersal of oil stranded in the littoral zone. Journal of the Fisheries Board of Canada, 35(5), 563-572.

Owens, E.H. (1985). Factors affecting the persistence of stranded oil on low-energy coasts. In International Oil Spill Conference Proceedings, 1985(1), 359-365. American Petroleum Institute. https:// doi.org/10.7901/2169-3358-1985-1-359

Owens, E.H., Prince, R.C. and Taylor, R.B. (2008). Shoreline Obser- vations and Sample Analysis Results from Black Duck Cove over 35 following the "Arrow" Oil Spill. Proc. 31th Arctic Marine Oilspill Program (AMOP) Technical Seminar, Environment Canada, Ottawa ON, 585-599.

Owens, E.H., Santner, R., Cocklan-Vendl, M., Michel, J., Reimer, P.D. and Stong, B. (2011). Shoreline Treatment during the Deepwater Horizon-Macondo Response. In International Oil Spill Conference Proceedings (IOSC), 2011(1), 271. American Petroleum Institute. http://ioscproceedings.org/doi/pdf/10.7901/2169-3358-2011-1-271

Owens, E.H., Sergy, G.A., Guénette, C.C., Prince, R.C. and Lee, K. (2003). The Reduction of Stranded Oil by In-Situ Shoreline Treatment Options. Spill Science \& Technology Bulletin, 8(3), 257-272. https://doi.org/10.1016/S1353-2561(03)00041-0

Owens, E.H. and Sergy, G.A. (2005). Time Series Observations of Marsh Recovery and Pavement Persistence at Three Metula Spill Sites after 301/2 Years. Proc. 28th Arctic and Marine Oilspill Programme (AMOP) Technical Seminar, Environment Canada, Ottawa ON, 463-472.

Owens, E.H., Taylor, E. and Humphrey, B. (2008). The Persistence and Character of Stranded Oil on Coarse-sediment Beaches. Marine Pollution Bulletin, 56(1), 14-26. https://doi.org/10.1016/j.marpolb ul.2007.08.020

Owens, E.H., Taylor, E., Gmur, S., An. C., Danner, G. and Lee, K. (2021). Shoreline Response Program (SRP) Decision Support Tool based on the Geographic Variability in Attenuation and Weathering of Oil Stranded in Canadian Marine Coastal Environments. Proc. International Oil Spill Conference Proceedings.

Owens, E.H., Teal, A.R. and Haase, P.R. (1991). Berm relocation during the 1990 shoreline cleanup program following the "Exxon Valdez" oil spill. Proc. 14th Arctic and Marine Oilspill Programme (AMOP) Technical Seminar, Environment Canada, Ottawa ON, 607-630.

Page, D.S., Boehm, P.D., Brown, J.S., Gundlach, E.R. and Neff, J.M. (2013). Fate of Oil on Shorelines. Oil in the Environment: Legacies and Lessons of the Exxon Valdez. Oil Spill, 116-143.

Percy, R.J. (1993). Canadian National Sensitivity Mapping Program. In International Oil Spill Conference Proceedings, 1993(1), 890890. American Petroleum Institute.

Percy, R.J., LeBlanc, S.R. and Owens, E.H. (1997). An integrated approach to shoreline mapping for spill response planning in Canada. In Inter-national Oil Spill Conference Proceedings, 1997 (1), 277-288. American Petroleum Institute.

Prince, R.C., Butler, J.D. and Redman, A.D. (2017). The Rate of Crude oil Biodegradation in the Sea. Environmental Science \& Technology, 51(3), 1278-1284. https://doi.org/10.1021/acs.est.6b03207

Prince, R.C., Garrett, R.M., Bare, R.E., Grossman, M.J., Townsend, T., Suflita, J.M., Lee, K., Owens, E.H., Sergy, G.A., Braddock, J.F., Lindstrom, J.E., Oudot, J. and Lessard, R.R. (2003). The Roles of Photooxidation and Biodegradation in Long-term Weathering of Crude and Heavy Fuel Oils. Spill Science \& Technology Bulletin, 8(2), 145-156. https://doi.org/10.1016/S1353-2561(03)00017-3

Prince, R.C., Garrett, R.M., Haith, C.E., Vandermeulen, J.H., Cobanli, S., Mossman, D.C. and Lee, K. (1998). The role of biodegradation in the weathering of oil from the 1970 Arrow spill. Proc. 21st Arctic and Marine Oil Spill Program (AMOP) Technical Seminar, Environment Canada, Ottawa ON, 717-727.

Prince, R.C., Owens, E.H. and Sergy, G.A. (2002). Weathering of an Arctic oil spill over 20 Years: the BIOS Experiment Revisited. Marine Pollution Bulletin, 44 (11), 1236-1242. https://doi.org/10.1016/ S0025-326X(02)00214-X

Reddy, C.M., Eglinton, T.I., Hounsell, A., White, A.K., Xu, L., Gaines, R.B. and Frysinger, G.S. (2002). The West Falmouth Oil Spill after Thirty Years: The Persistence of Petroleum Hydrocarbons in Marsh Sediments. Environmental Science \& Technology, 36 (22), 57544760. https://doi.org/10.1021/es020656n

Spaulding, M.L. (2017). State of the art review and future directions 
in oil spill modeling. Marine Pollution Bulletin, 115(1-2), 7-19. https://doi.org/10.1016/j.marpolbul.2017.01.001

Superior, (undated). Thunderstorm Hazards. City of Superior Hazard Mitigation Plan Update, Section 8, 24 pp. http://www.ci.superior.w i.us/DocumentCenter/View/1533/Section-8-Thunderstorm-Hazard? bidId=(accessed 25 January 2021).

Taylor, E., Owens, E.H., Lee, K., An, C. and Chen, Z. (2021). A Review of Numerical Models for Oil Penetration, Retention and Attenuation on Shorelines. Journal of Environmental Informatics Letters, in press.

Taylor, E. and Reimer, P.D. (2008). Oil Persistence on Beaches in Prince William Sound-A Review of SCAT Surveys Conducted from 1989 to 2002. Marine Pollution Bulletin, 56(3), 458-474. https://doi. org/10.1016/j.marpolbul.2007.11.008

The Climate Atlas of Canada. (2020). "Cold Weather: Frost Days" and "Agriculture: First Day of Fall Frost" in The Climate Atlas of Canada. https://climateatlas.ca/map/canada/frostdays_2060_85\#lat= $60.5 \& \operatorname{lng}=-82.97 \& \mathrm{z}=3$, and https://climateatlas.ca/map/canada/firstf all_2060_85\#lat=60.5\&lng=-82.97\&z=3 (accessed 25 January 2021)

Ward, C.P. and Overton, E.B. (2020). How the Deepwater Horizon spill reshaped our understanding of crude oil photochemical weathering at sea: a past, present and future perspective. Environmental Science: Processes \& Impacts, 22(5), 1125-1138. https://doi.org/1 0.1039/sD0em00027b
Wilson, G.W., Hay, A.E. and Bowen, A.J. (2014). Observations of wave shear stress on a steep beach. Journal of Geophysical Research: Oceans, 119(11), 7827-7839. https://doi.org/10.1002/2014 JC010193

Wright, L.D. and Short, A.D. (1984). Morphodynamic variability of surf zones and beaches: A synthesis. Marine Geology, 56(1-4), 93119. https://doi.org/10.1016/0025-3227(84)90008-2

Wynja, V., Demers, A-M., Laforest, S., Lacelle, M., Pasher, J., Duffe, J., Chaudhary, B., Wang, H. and Giles, T. (2015). Mapping Coastal Information across Canada's Northern Regions based on LowAltitude Helicopter Videography in Support of Environmental Emergency Preparedness Efforts. Journal of Coastal Research, 31(2), 276-290. https://doi.org/10.2112/JCOASTRES-D-14-00059.1

Zhao, L., Boufadel, M.C., Geng, X., Lee, K., King, T., Robinson, B. and Fitzpatrick, F. (2016). A-DROP: A predictive model for the formation of oil particles aggregates (OPAs). Marine Pollution Bulletin, 106 (1-2), 245-259. https://doi.org/10.1016/j.marpolbul.20 16.02.057

Zito, P., Podgorski, D.C., Baretges, T., Guillemette, F., Roebuck, J. A. Jr., Spencer, R.G.M., Rogers, R.P. and Tarr, M.A. (2020). SunlightInduced Molecular Progression of Oil into Oxidized Oil Soluble Species, Interfacial Material, and Dissolved Organic Matter. Energy \& Fuels, 34 (4), 4721-4726. https://doi.org/10.1021/acs.energyfuel s.9b04408 